\title{
Cerebral Proliferative Angiopathy: Case Report
}

\section{Angiopatia cerebral proliferativa: relato de caso}

\author{
Luana Antunes Maranha Gatto ${ }^{1}$ Rodrigo Tavares Brisson ${ }^{2}$ Zeferino Demartini jr ${ }^{3}$ Gelson Koppe ${ }^{4}$ \\ Carlos Rocha $\mathrm{Jr}^{5}$
}

${ }^{1}$ Hospital Universitário Cajuru, Curitiba, PR, Brazi

${ }^{2}$ Division of Neurology, Department of Interventional

Neuroradiology, Hospital Universitário Cajuru, Curitiba, PR, Brazil

${ }^{3}$ Department of Neurosurgery and Interventional Neuroradiology,

Hospital Universitário Cajuru, Curitiba, PR, Brazil

${ }^{4}$ Department of Interventional Neuroradiology, Hospital

Universitário Cajuru, Curitiba, PR, Brazil

${ }^{5}$ Department of Neurology, Neurosurgery, Interventional

Neuroradiology, Campo Grande, MS, Brazil

Arq Bras Neurocir 2018;37:131-133.

\begin{abstract}
Address for correspondence Luana Antunes Maranha Gatto, Hospital Universitário Cajuru, Av. São José, 300 - Cristo Rei, Curitiba - PR, 80050350, Brazil (e-mail: luanamaranha@yahoo.com.br).
\end{abstract}

\author{
Abstract \\ Keywords \\ - intracranial \\ arteriovenous \\ malformations \\ - central nervous \\ system vascular \\ malformations \\ - therapeutic \\ embolization \\ - endovascular \\ procedures
}

Proliferative angiopathy (PA) is a rare cerebral vascular disease in which anomalous vessels continually recruit additional feeder arteries, amid a functional brain parenchyma. We report the case of a young woman with progressive history of headache, motor deficit, seizures and drowsiness. She received a misdiagnosis of brain arteriovenous malformation (AVM) and evolved with dysarthria and cognitive decline after an unsuccessful embolization performed at another institution. We opted for conservative treatment with periodic control by imaging tests. Proliferative angiopathy differs in natural history, prognosis, histopathology and treatment of the usual AVMs. Endovascular procedures aggravate the neurological deficits, which are usually progressive and tend to worsen over time.

A angiopatia proliferativa (AP) é uma doença vascular cerebral rara em que vasos anômalos recrutam continuamente artérias nutridoras adicionais em um parênquima cerebral normal. Relatamos um caso de uma mulher jovem com história progressiva de cefaleia, déficit motor, convulsões e sonolência. Ela recebeu um diagnóstico incorreto da malformação arteriovenosa (MAV) cerebral e evoluiu com disartria e declínio cognitivo após uma embolização malsucedida realizada em outra instituição. Optamos pelo tratamento conservador com controle periódico por testes de imagem. A AP difere das MAVs usuais em relação a história natural, prognóstico, histopatologia e tratamento. Os procedimentos endovasculares agravam os déficits neurológicos, que geralmente são progressivos e tendem a piorar ao longo do tempo.

- embolização terapêutica

- procedimentos endovasculares

received

October 24, 2017

accepted

January 23, 2018

published online

April 17, 2018
DOI https://doi.org/

10.1055/s-0038-1642604. ISSN 0103-5355.
Copyright $(2018$ by Thieme Revinter

Publicações Ltda, Rio de Janeiro, Brazil
License terms

(c) (1) $\ominus$ (\$) 


\section{Introduction}

Diffuse arteriovenous malformations (AVMs) of the central nervous system, also called proliferative angiopathy $(\mathrm{PA})$, are large lesions that can occupy an entire cerebral hemisphere and cause mainly intractable seizures, motor deficits and other symptoms. In PA, anomalous vessels continue to recruit additional feeder arteries, ${ }^{1}$ making their architecture, natural history, clinical presentation and treatment distinct from usual AVMs. ${ }^{2}$ The cerebral PA is associated with the presence of a viable cerebral parenchyma, in which it differs from usual AVMs and has important implications in the therapeutic decision in patients with this rare vascular pathology. 2,3 Attempts to treat this condition are indicated in extreme cases, such as intractable epileptic seizures, for example, although with great risks of aggravating the neurological deficits. ${ }^{2,4} \mathrm{We}$ report a case of PA in an adolescent, its evolution and management regarding clinical and imaging findings.

\section{Case Report}

A 15-year-old female patient presented with 5 years of headache and progressive right hemiparesis. One year earlier, she had been admitted at her city's hospital after generalized seizure and progressive drowsiness, and that was when she received the misdiagnosis of brain AVM through a simple brain computed tomography (CT). An unsuccessful embolization with n-butyl cyanoacrylate was attempted, evolving with cognitive worsening and dysarthria. The patient was referred to our interventional neuroradiology department presenting a proportionate right hemiparesis (muscle strength grade $4 / 5$ ), spasticity, postural instability, right ataxia; exacerbated deep appendicular reflexes on the right side (grade 3/4), with plantar cutaneous reflex in extension bilaterally. The cerebral digital subtraction angiography (DSA) ( - Fig. 1) showed the nidus of a bulky vascular malformation affecting the entire left hemisphere fed by right anterior, middle and posterior cerebral arteries, and superficial venous drainage (Spetzler-Martin grade $V$ ). No flow or intranidal aneurysms were identified. An encephalic magnetic resonance image (MRI) (-Fig. 2) evidenced an extensive vascular malformation with numerous ectasias and "flow void" affecting the entire left hemisphere. We opted for conservative treatment with outpatient followup and periodic control by imaging tests.

\section{Discussion}

Cerebral PA has been described in a series of cases, predominantly affecting young adult female patients, with onset of symptoms, on average, at 17 years-old and representing 3.4\% of the diagnosed vascular malformations. ${ }^{2}$ The most common form of clinical presentation are seizures; other less frequent presentations are headache, intracranial hemorrhage and focal neurologic deficits. ${ }^{2,3,5-8}$ The usual morphology on cerebral CT or MRI is characterized by diffuse vascular lesions interspersed with normal brain parenchyma. The DSA of cerebral vessels does not show dominance of a feeder artery; the nidus is generally larger than $6 \mathrm{~cm}$ with difficult delimitation; and

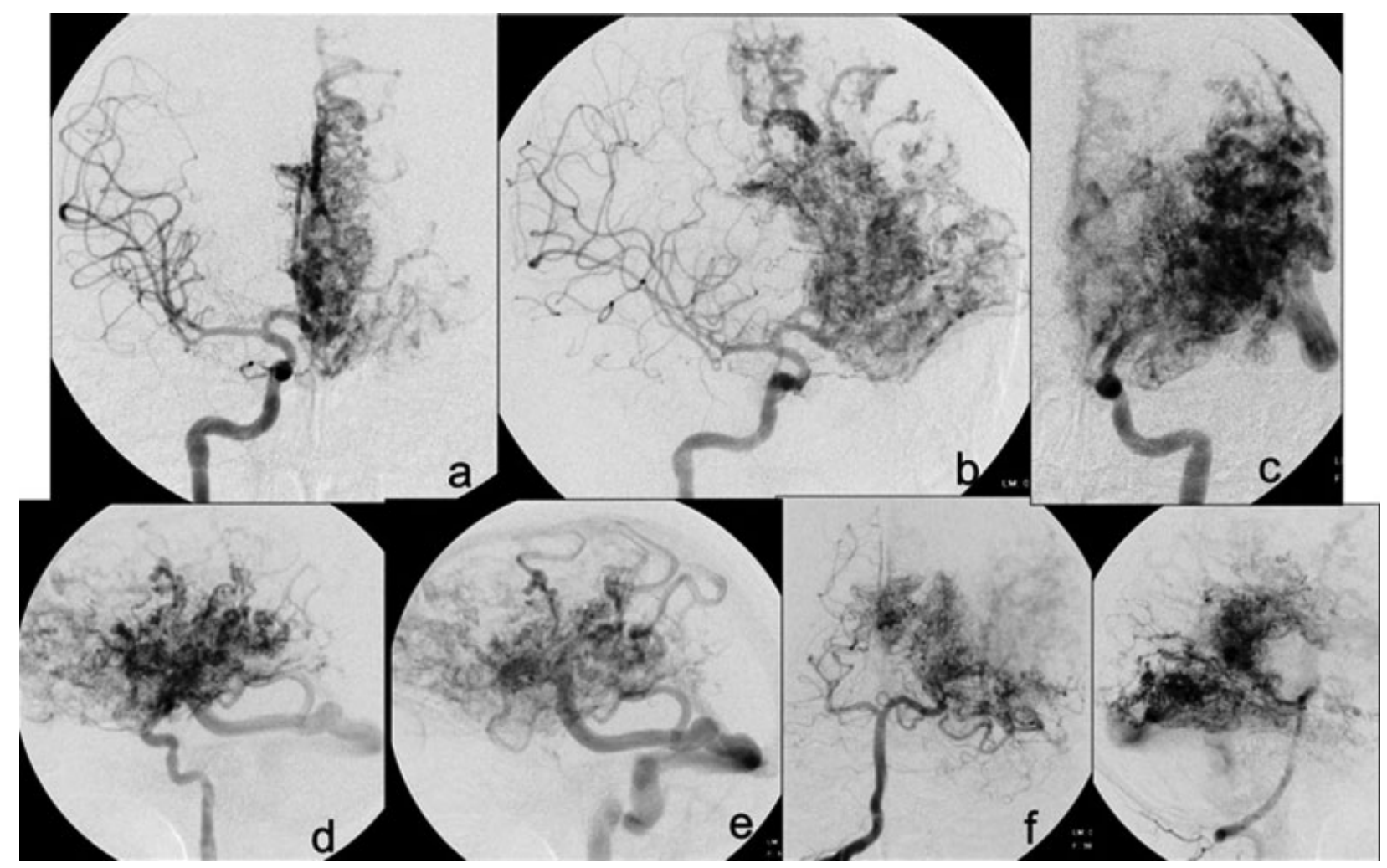

Fig. 1 Angiography. (a) RICA AP; (b) RICA RAO; (c) LICA AP; (d) LICA Lat; (e) LICA Lat late phase; (f) RVA AP; (g) RVA Lat. Abbreviations: AP, anteroposterior; Lat, lateral; LICA, left internal carotid artery; RAO, right anterior oblique; RICA, right internal carotid artery; RVA, right vertebral artery. 


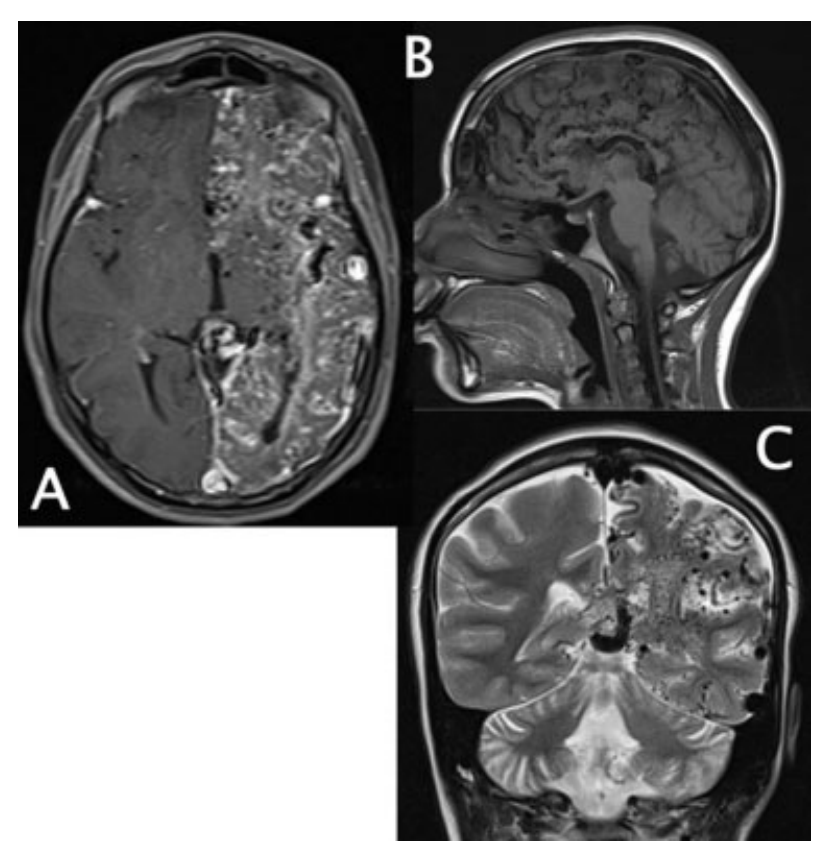

Fig. 2 Resonance with extensive ectasias and "flow void" throughout the left hemisphere. (a) axial T1 with contrast; (b) sagittal T1; (c) coronal T2.

venous drainage does not have ectasia, in most cases. ${ }^{2,3}$ In the histopathological analysis, the lesions are described as an intraparenchymal vascular proliferation, with irregular and dilated arterioles but normal aspect and veins with thickening due to collagen fibers. ${ }^{2}$ The treatment must be considered according to the characteristics of histological findings. Since those lesions are intermingled with healthy brain parenchyma, surgery, radiotherapy and endovascular treatment have not been routinely recommended due to the risk of permanent neurologic deficits already described in the literature. Invasive techniques are reserved for cases of epilepsy and headache refractory to clinical treatment. ${ }^{2,5,8}$
According to the literature, after an incorrect diagnosis and an unrecommended embolization, there was worsening of the focal deficits.

\section{Conclusion}

The identification of cerebral PA as a distinct entity among other vascular malformations is extremely important, since its natural history, treatment and prognosis are very different from the usual and more frequent AVM.

Conflict of Interest

The authors declare that there are no conflicts of interest.

\section{References}

1 Osborn AG. Angiografia Cerebral Diagnóstica; in Revinter 2. ed. Rio de Janeiro, RJ; 2002:447

2 Lasjaunias PL, Landrieu P, Rodesch G, et al. Cerebral proliferative angiopathy: clinical and angiographic description of an entity different from cerebral AVMs. Stroke 2008;39(03):878-885. Doi: 10.1161/STROKEAHA.107.493080

3 Rohit, Goh PS. Diffuse Proliferative Cerebral Angiopathy: A case report and review of the literature. J Radiol Case Rep 2015;9(09): 1-10. Doi: 10.3941/jrcr.v9i9.2402

4 Eesa M, Sharma P, Goyal M. Cerebral Proliferative Angiopathy. Can J Neurol Sci 2009;36(02):242-243

5 Biasi PR, Almeida TAL, Espanhol RA, et al. Cerebral Proliferative Angiopathy -Description of a Rare Clinical Entity. Arq Bras Neurocir 2015;34(01):82-85. Doi: 10.1055/s-0035-1547393

6 Dória-Netto HL, Souza-Filho AM, Dória-Netto RH, et al. Cerebral proliferative angiopathy. Arq Neuropsiquiatr 2010;68(02): 300-302. Doi: $10.1590 /$ S0004-282 × 2010000200027

7 Gold JJ, Crawford JR. Acute hemiparesis in a child as a presenting symptom of hemispheric cerebral proliferative angiopathy. Case Rep Neurol Med 2013;2013:920859. Doi: 10.1155/2013/920859

8 Liu P, Lv X, Lv M, Li Y. Cerebral proliferative angiopathy: Clinical, angiographic features and literature review. Interv Neuroradiol 2016;22(01):101-107. Doi: 10.1177/1591019915609784 